\title{
The Line Between Politics and Conspiracy Theories: Tracking Disinformation using \#StopTheGreatReset
}

What is the 'Great Reset'?

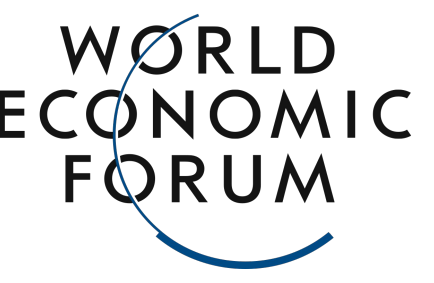

Research Process:

1. Preliminary Twitter research

2. Creation of database

3. Collecting links

4. Next steps

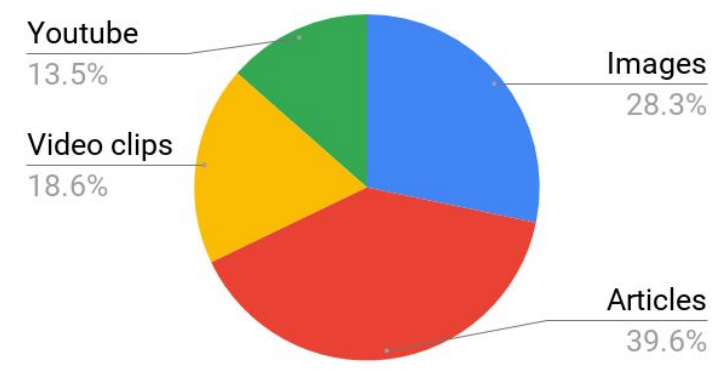

News

Abp. Viganò warns Trump about 'Great Reset' plot to 'subdue humanity,' destroy freedom

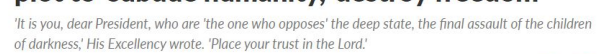

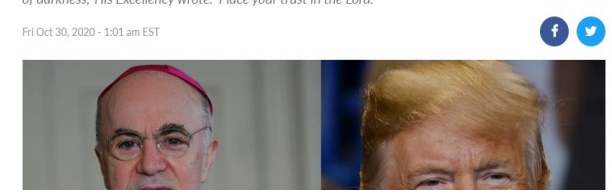

digital sie social economic policy canada years
power first january ${ }_{\text {media }}$ news people ago biden der ife states get time new covid 2020 just trump much $\underset{\text { make }}{\operatorname{com}} \underset{\text { com }}{\operatorname{mon}}$ global world reset also public day

make com gree must

2021 vaccine use $^{\text {know united }}$ coronavirus data now government tweets

virus need even schwab privacy control 000

today president terms schwab privacy show

fourth big human $\begin{aligned} & \text { business industili } \\ & \text { subseribe search }\end{aligned}$

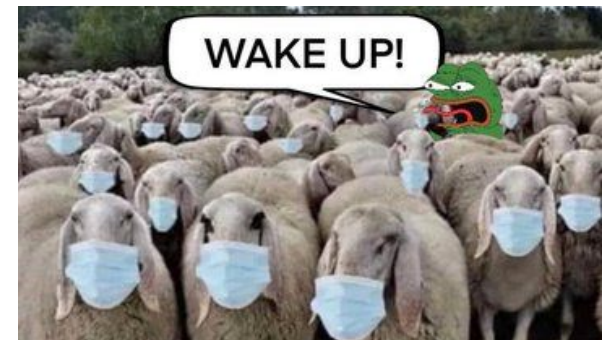

Key Takeaways:

Research conclusions:

1 .inflated narratives

2.interconnectivity of theories

Challenges: systematic data collection

Learning: preliminary research 